\title{
A public secret: assisted living, caregivers, globalization
}

\author{
By Kathleen Woodward*
}

\begin{abstract}
Frail elderly and their caregivers are virtually invisible in representational circuits (film, the novel, photography, television, the web, newspapers), with the elderly habitually dismissed as non-citizens and their caregivers often literally not citizens of the nation-states in which they work. How can we bring what is a scandalous public secret of everyday life into visibility as care of the elderly increasingly becomes a matter of the global market in our neoliberal economies? This essay explores the representation of caregivers and elders, together, in photographs, the memoir, news and feature stories, and documentary film, suggesting that one of the most effective modes of advocating for changes in public policy is engaging people's understanding through stories and images. In this study, I consider stories of assisted living, which involve elders, who are white, and paid caregivers, who are people of color, gendered female, and part of global care chains; these stories include American writer Ted Conover's New York Times Magazine feature story "The Last Best Friends Money Can Buy" (1997) and Israeli Tomer Heymann's documentary film "Paper Dolls" (2006). Of key importance is a feeling of kinship as new forms of the family take shape.
\end{abstract}

* Kathleen Woodward, Simpson Center for the Humanities and Department of English, University of Washington, Seattle, USA 
International Journal of Ageing and Later Life

Keywords: Caregivers, frail elderly, gender, race, global care chains, representation, memoir, documentary, advocacy.

I

Consider three photographs. First, a black-and-white photograph of an old woman sitting alone, head bowed, body enclosed by a walker. Has she been shopping? It would not seem so. Is she waiting for a bus? It seems unlikely. Is she just waiting, with nothing to occupy her and no expectation that someone will come to retrieve her? That would seem to resonate with the bleak mood conveyed by this gray environment of concrete and crumbling brick, an imposing trash can to the left, no traces of life in sight, not even a Beckettian tree, nothing other than the frail old woman to the right who herself seems devoid of life.

The psychoanalyst D. W. Winnicott has astutely observed that there is no such thing as a baby, by which he meant that an infant cannot survive except in relation to his mother; together they form an inseparable

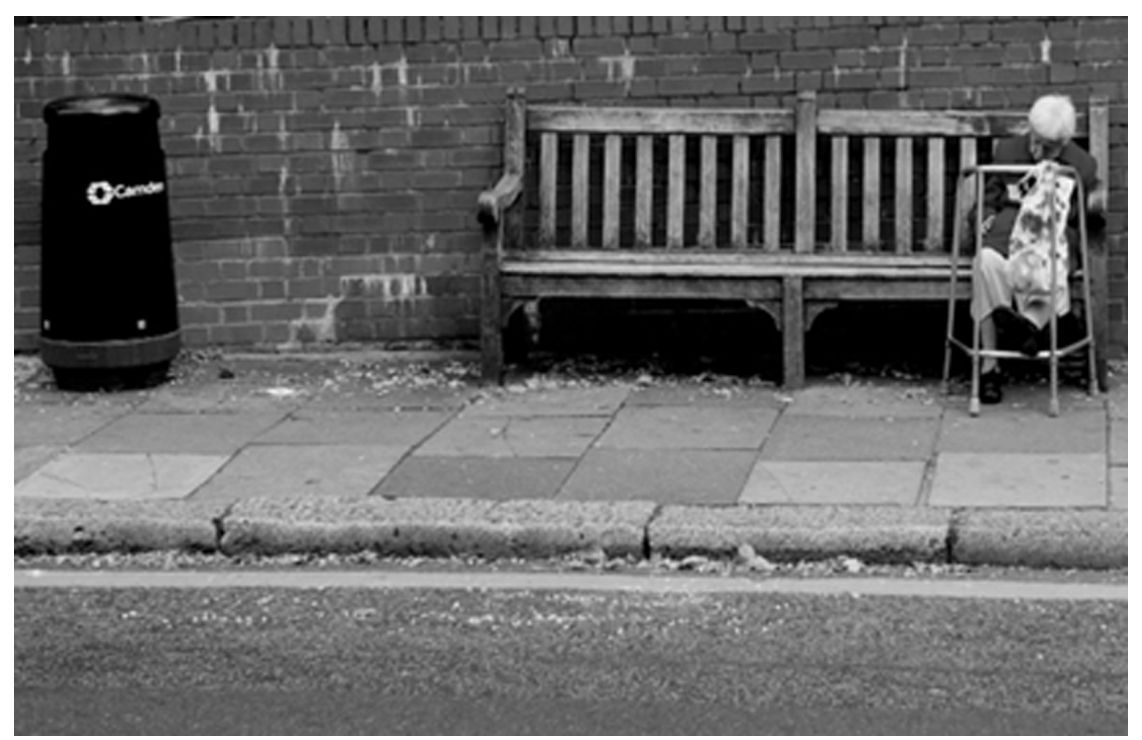


pair, one dependent upon the other, each in thrall to the other. As this dispiriting photograph attests, there is such a thing as a solitary old person in need of care, concern, and connection to a vital intimate world. For this woman, there is no home in sight to provide a trusted shelter for care. She does not seem to belong - anywhere.

Not behind closed doors where we would expect to find her, she is outside, although there are no eyes to see her other than ours as spectators of the photograph. The photograph thus reveals what media artist and activist Sharon Daniel calls a public secret (2007). "There are secrets that are kept from the public and then there are 'public secrets' - secrets that the public chooses to keep safe from itself," she explains. "The public secret is an irresolvable internal contradiction between inside and outside, power and knowledge." The denial of the scandalous isolation of old people in our societies is a public secret, one the public chooses to keep from itself. As this photograph suggests, old people, particularly those who are frail, are habitually imagined as non-citizens, if not embodiments of bare life. ${ }^{1}$

Next, consider the black-and-white photograph "Mature and Young Hands" by Lars Klove. The laying on of hands is an iconic gesture of comfort and healing, and the mood of this photograph is calm, suggesting a world in which people in need of affection, as are we all, receive it, and in which intimacy is eloquent in its wordlessness. I see two women at rest, sitting together on a couch, inside.

Does racial or ethnic difference figure in what is ostensibly the small world of these two women? It is difficult to tell, but it does not seem so. The two could easily be mother and daughter-and in fact to me their hands do resemble each other. The younger woman might be a paid caregiver. That we can discern little about these women and their environment seems to imply that fundamentally there is not so much difference between them. But this interpretation obscures the all-important relationship between power and knowledge that Sharon Daniel identifies

\footnotetext{
${ }^{1}$ I found this photograph in 2011 on the homepage of "Oecumene: Citizenship after Orientalism," a research project at the Open University exploring how the concept of citizenship is being refigured in the face of large-scale political change around the globe, in particular across the boundaries of nation-states.
} 
International Journal of Ageing and Later Life

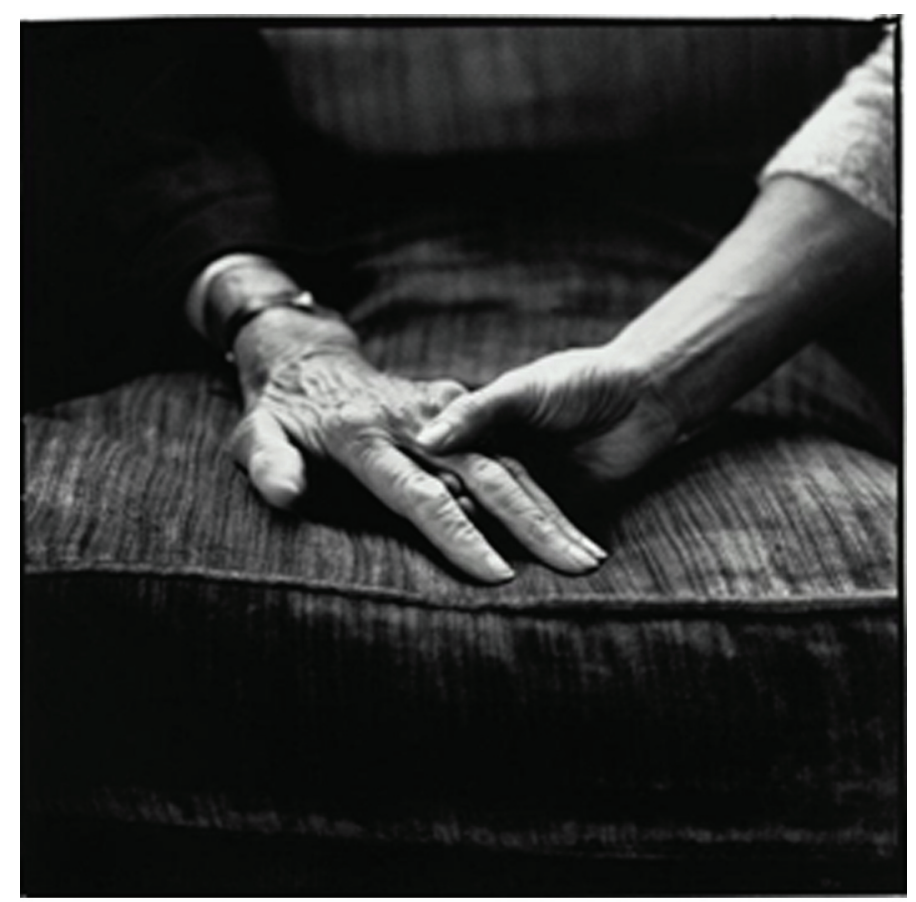

Lars Klove, "Mature and Young Hands," Getty Images

as constitutive of a public secret. If the photograph of the old woman alone on a bench testifies to the need to integrate people in old age as full citizens in a society based on mutually interdependent generations, this photograph suggests that a solution is simple - the warmth of care. But the situation of frail older people across communities and nation-states is anything but simple, and there is no uncomplicated solution to propose as a response. Moreover, their caregivers, many of whom have crossed national borders in order to find work, are in many cases literally not citizens of the nation-states where they offer care, and there is no social contract to speak of worthy of the name.

In 2008, at a conference on women, ageing, and the media at the University of Gloucestershire, I gave a talk on assisted living, focusing on American narratives (fictional and documentary) about women of the 
A public secret

fourth age and invoking feminist philosopher Eva Kittay's (1999) influential work on dependency and care. ${ }^{2}$ Kittay argues that corporeal dependency - embodied in infancy and childhood, frail old age, severe disability, and sickness - is an elemental condition of all of our lives; she insists that as a fundamental relationship between people, dependency should be the foundation for theorizing and shaping our social institutions, not the autonomous individual on which the liberal theory of the state is based. Kittay calls attention to the appalling lack of social justice in the American health-care system, with many families as well as individuals in extreme jeopardy. Acutely aware of the physically exhausting and psychically painful work of caring for those who are seriously sick, she underlines the fact that this labor-what she calls dependency work - is largely invisible to us and shamefully unacknowledged by our society. ${ }^{3}$

I agree with Kittay's basic argument. But in retrospect, I realize that in concentrating in Gloucestershire on frail older women in need of care, I gave no attention to the giver of care, thereby repeating the mistake of focusing on the frail elder and ignoring the experience of the caregiver. This egregious oversight is encapsulated in a 2008 New York Times story about the use of Montessori methods with those who have Alzheimer's disease (Leland). The lead image — this is my third photograph — exposes a public secret not pursued in the story itself, one involving race, gender, and class as well as age:

\footnotetext{
${ }^{2}$ For a companion piece to "Public Secrets" from that conference, see Woodward 2012. Referring to the work of caring for others, Kittay 1999 insists, "The labor, when well done, is aptly characterized by Jane Martin's three 'Cs': care, concern, and connection. It is the work of tending to others in their state of vulnerabilitycare. The labor either sustains ties among intimates or itself creates intimacy and trust - connection. And affectional ties - concern - generally sustain the connection, even when the work involves an economic exchange. For the dependency worker, the well-being and thriving of the charge is the primary focus of the work" (31). See Whitney 2011 who, engaging Kittay, argues that in order to strengthen the idea of dependency as grounding personhood we must disentangle it from the dichotomy of vulnerability and power.

${ }^{3}$ The academic literature on care across disciplines has grown enormously in recent years. Three studies I have found especially helpful from geography and anthropology are England 2010; Lawson 2007; Mol et al. 2010).
} 
International Journal of Ageing and Later Life

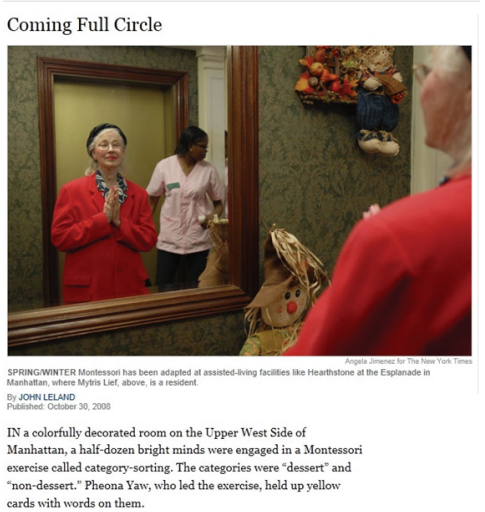

An attractive elderly white woman is smiling into the mirror at her own image, which is reflected back to us as spectators. She is being aided by a black woman who appears in the background, her face turned away from the camera eye. The unequal structural relationship between white women and women of color, in terms of elder care, is a public secret. Subject to the mutually reinforcing prejudices of ageism and sexism, and suffering from chronic conditions, frail elderly women are virtually unrepresentable in mainstream visual media which thrive on dramatic - not to say, melodramatic - narration. What attracts public attention in terms of our biological futures are not chronic conditions, which are generally understood as mundane by those who do not suffer them, but the specter of epidemics of infectious disease and narratives of mutated bodies. ${ }^{4}$ If frail elderly women are invisible, it is even more unlikely that we will find caregivers of the elderly represented, especially so given, as in this photograph, the differentials of race.

Considered in turn and taken together, these three photographs serve to introduce the impulse animating my essay on assisted living for the frail elderly as well as the approach I take. As the first photograph suggests, that the frail elderly, often tragically isolated, require care should be a matter of public concern, not a public secret. As the second photograph implies, we need to consider care in terms of comfort and intimacy, not just

${ }^{4}$ See Cohen 2011; Wald 2008. 
in terms of so-called practical matters. And as the third photograph intimates, we need to widen the scope of the picture, beyond a close-up of hands, to include the social context of the relationship between people requiring care and those offering it; so many things matter, in this case, especially race. How can we bring what is a scandalous public secret of everyday life into visibility as care of the elderly increasingly becomes a matter of the global market in our neoliberal economies? This essay explores the representation of caregivers and elders together, not separately, suggesting that one of the most effective ways of creating moral communities and advocating for change in public policy is by telling stories that draw us into the affective worlds of other people. My focus is first and foremost on the caregivers.

Stories constitute essential equipment for living. ${ }^{5}$ Where do we find stories of those who take care of the elderly? Stories are being told in America by mid-life feminists who find themselves providing care - or often more accurately, coordinating care - for their elderly parents. ${ }^{6}$ Stories are being told by wives whose older husbands have suffered from debilitating illnesses - a devastating fall, stroke, cancer. ${ }^{7}$ In these cases, care is underwritten by an obligation typically understood to rest with those who occupy a certain status - daughters and wives - and thus vanishes into the "natural" rhythm and organization of social life.

My concern, however, is not with wives and daughters, but with the paid caregiver of the frail elderly, a figure even less visible in representational circuits than the frail elderly themselves. More specifically, I' $m$ interested in caregivers of the elderly who form global care chains, a phenomenon born of the intersection of population aging and globalization. ${ }^{8}$ How do cultural texts give voice to the experience of these caregivers? How are relationships

\footnotetext{
${ }^{5}$ I am alluding to a 2007 book-length collection of essays by U.S. anthropologist Barbara Myerhoff beloved for her work with elderly communities.

${ }^{6}$ See Fuchs 2005; Barnes 2010; Miller 1996; medical anthropologist Margolies 2004, Margolies 2010; Geist 2009; Maierhofer 2010; Simmons 1996; and Kane \& West 2005. See also the memoir by the British writer Gillies 2009. Memoirs, both long and short, are also being written by sons about taking care of the elderly fathers; see Roth 1991; Rauch 2010.

${ }^{7}$ See Shulman 2008; Ackerman 2011; Sheehy 2010.

${ }^{8}$ On global care chains see Hochschild 2000.
} 
International Journal of Ageing and Later Life

between caregivers and elders portrayed? What strategies of storytelling draw us into the worlds of caregivers and elders?

In what follows, I turn to four stories of assisted living. They appeared between 1997 and 2009 and represent four distinct genres. The first three-a book-length memoir, a news story that takes on national policy significance in America, and long-form feature-story journalism - were published in the United States. The fourth is a documentary film made in Israel that has a global reach. All involve caregivers who are people of color and are gendered female, elders who are white. In all of them, care is part of the market economy - it is paid care - but the relationship between caregivers and elders is not necessarily polluted by being mediated by the market. For the caregivers, the discourse of family - or more generally an ethic of careis central. They represent themselves as caring people, and in three of the stories the feeling of family between caregiver and elder is palpable (in two stories, the agency brokering the relationship between caregiver and the frail elder is indicted as uncaring by the caregivers themselves, but in another story, the agency is presented as a force for good). If the site of care in three stories is the home, the global geography of care takes us from the United States to Israel, with caregivers coming from America, Jamaica, and the Philippines. But these are generalizations. They do not account for the particularity of these stories - the texture of experience and the force of the narrative. All of them, albeit differently, have power to engage us.

The first story-A Place Called Canterbury, the book that revealed my blind spot to me - introduces the figure of the caregiver, a woman of color who, taking care of a white woman, is easily overlooked; Canterbury implicitly asks us to follow her life beyond its pages and into the future. The second story follows Jamaican-born Evelyn Coke into a grim period in her own difficult old age, also distinguished by her remarkable resolve to fight for social justice for herself and for others. The third and fourth stories - a long piece in the New York Times Magazine entitled "The Last Best Friends Money Can Buy" and the film Paper Dolls_-provide more ample portraits of the lives of caregivers, who are predominantly in their thirties. In these two stories we are drawn more fully into their worlds caring for elders and, importantly, learn about other dimensions of their lives as well. The film is the most complex of the texts I consider and I devote the most space to it. 
A public secret

II

"We is family."

At the conference in Gloucestershire I discussed Dudley Clendinen's A Place Called Canterbury: Tales of the New Old Age in America (2008), an absorbing book-length account of his mother's decade-long decline in Canterbury Tower's Health Center, the nursing wing of a non-profit, continuing-care facility in Tampa, Florida. Clendinen provides two major frames for his mother's story: the stories of other Canterbury residents who captured his interest and the story of his relation to his mother throughout this long ordeal. His mother, unable to speak or feed herself after two strokes in rapid succession, suffered from arthritis, scoliosis, high blood pressure, and osteoporosis, and was confined to a wheelchair and then to bed for over nine years.

Embedded in A Place Called Canterbury is an important back story, one that I did not consider then and bring into focus here. Louise Edwards, his mother's long-time maid (they had been together for some 20 years), is introduced early in the first chapter, before his mother had suffered her two incapacitating strokes. In 1998 Clendinen flies from Baltimore down to Tampa, arriving to find that Louise is with his mother, who had fractured her spine:

\footnotetext{
I flew down and found Mother in a room in the nursing wing, tucked and propped between pillows in bed, hair coiffed and make-up perfect, looking lovely. There was lunch on a tray. Louise Edwards, her maid, had brought china and silver down from the apartment and was sitting on a chair next to the bed. On a rolling table, between them, was Mother's silver ice bucket, with a silver spoon beside it.

"Louise, dahlin," Mother said, with a sign, "feed me summah that crushed ice withah spoon."

Louise opened the lid of the bucket, spooned up a shiny little mound of ice, and held it, dripping. Mother smiled at her and opened her mouth, and Louise slid the spoon in. Munch, munch. Mother looked content.

Louise came every day. (19-20)
}

After his mother's second stoke, Clendinen and his sister ask Louise to come back to help, and she continues to care for his mother, along with nurses and certified nursing assistants, with love and grace, coming to 
International Journal of Ageing and Later Life

Canterbury Tower three times a week, keeping her company, fussing over her, singing hymns to her, brushing her hair, and applying her makeup, until she died. Clendinen stresses his mother's almost uncannily beautiful appearance, and, as the son tells the story, Louise's work was in great part devoted to preserving her mother's look of femininity. This he doesn't understand as a peculiar indulgence. Rather he is grateful that Louise, as he puts it, "paid attention to all the details of choice remaining in my mother's tiny, restricted life" (148).

Louise comforted his mother the way his mother had comforted her own children when they were sick. If Clendinen understands his mother's care and comfort not as an extravagance but as an instance of reciprocity (although displaced), he is keenly aware that he is not the one providing bodily care and continuing emotional support. Structurally there is an asymmetry here. Louise Edwards is the third term which does not, in the Freudian sense, separate mother and son; rather she brings them together.

Although Clendinen doesn't devote much space to Louise, her presence permeates the entire book. We learn very little about her, however. We don't know where she was born, how old she is, or if she has a family. We do learn that she is, as Clendinen puts it, dark. But in terms of the connection between these two women, we are told what is essential:

She reacted happily to my sister, Melissa, when she visited, and to me when I came down from Baltimore or New York, but increasingly, I thought, it was to her maid and companion, Louise Edwards, who attended her, fed her, and kept her company three days a week, that Mother was most responsive.

"Louise loves you, Mama," Louise said, looking into my mother's eyes, holding her hand. "Louise loves you." The look in my mother's eyes - the feeling she gave backwas unmistakable. (75)

"The most important, the most caring and intimate relationship in my mother's life," Clendinen writes, was "with Louise" during this long period (149). It was Louise who knew his mother's moods and who bought her clothes and watched his mother for signs of decline. And Louise? Clendinen asks her if she would prefer the term "housekeeper" to "maid." This is her vociferous response:

"No!" Louise said, flaring. She gave me a scowl of displeasure, as if I'd said something offensive. She turned to my mother, then back to me, still holding Mother's hand. 
A public secret

"Ah is yo' mothuh's maid!" she said. "This is puss-onal." She stared at me, unblinking. "We is family." (pp. 149-50)

What is the familial structure as imagined by Louise? Louise thought of her, she told Clendinen, as her own mother. And Clendinen himself? "It's what I feel... it all just feels like family. We're all together, until the end" (150). ${ }^{9}$

At the end of the book, after his mother's death, Clendinen names the members of his mother's small circle of family who are left behind. There are six of them, one of whom is Louise. I wonder, what has happened to her? I wonder, was he in touch with her before he died in 2012? Clendinen's mother received superb care, her long last years accompanied by kindness and love. His mother had the material means to sustain that care. What does the future hold for Louise Edwards? Who will care for her?

\section{"I hope they try to help me because I need help bad."}

In August 2009, a story by Douglas Martin in the New York Times reported the death of Jamaican-born Evelyn Coke at the age of 74. I excerpt below a little over a quarter of this long news story:

\footnotetext{
Year in and year out, Evelyn Coke left her Queens house early to go to the homes of elderly, sick, often dying people. She bathed them, cooked for them, helped them dress and monitored their medications. She sometimes worked three consecutive 24-hour shifts.

She loved the work, but she earned only around $\$ 7$ an hour and got no overtime pay. For years Ms. Coke, a single mother of five, quietly grumbled, and then, quite uncharacteristically, rebelled. In a case that reached the Supreme Court in April 2007, Ms. Coke sued to reverse federal labor regulations that exempt home care agencies from having to pay overtime.
}

\footnotetext{
${ }^{9} \mathrm{I}$ am well aware that the rhetoric of family-especially when invoked in someone's home that is simultaneously a site of paid care-can mask an asymmetrical, exploitative relationship between caregivers and their employers. Here, however, I emphasize the testimony of caregivers who take pride in their commitment to care and who value the intimacy that nevertheless can emerge from sites of paid care. See Stacey 2011. I also emphasize the vulnerability of both caregiver and elder, a condition that may work to mitigate the destructive effects of differentials in power and enhance closeness.
} 
International Journal of Ageing and Later Life

\footnotetext{
"I hope they try to help me because I need help bad," she said in April 2007 after listening to oral arguments. She had stopped working after being hurt in a car accident six years earlier, and by then used a wheelchair.

The court unanimously rejected her claims ...

Her health deteriorated until she died of heart failure on July $9 \ldots$

As a symbol, Evelyn Coke remains alive as both Congress and the Obama administration review regulations that carry out amendments to a 1938 law on wages. In June, 15 senators and 37 house members wrote to Hilda L. Solis, secretary of labor, urging her to eliminate the exemption for home attendants.

"Evelyn Coke, who took a case all the way to the Supreme Court, spent two decades working more than 40 hours a week caring for others," the senators wrote. "Yet, when she suffered from kidney failure, she could not afford a health care worker to take care of her."
}

In the United States, as a result of federal legislation and regulations dating from the 1930s and the 1970s, there is no requirement at the national level that home care workers be paid either minimum wage or overtime (ironically, one of the reasons why home health care workers were excluded from these labor laws and regulations was to protect the home as a site of privacy). As an employee of Long Island Care at Home, Evelyn Coke, since immigrating to the United States from Jamaica in the 1970s, had taken care of the elderly; she received no overtime pay, and in a cruel irony, no health benefits. In the last years of her life Coke needed dialysis three times a week and, as the news story underscores, was unable to afford a health care worker to take care of her, her physical suffering exacerbated by her vulnerable position as a poor, old, black woman from Jamaica. A woman who cared for others and who, in her own old age, could not secure such help for herself, she sued for redress.

Notwithstanding the failure of her lawsuit, which was ultimately tried by the Supreme Court, Evelyn Coke, both in late life and in death, has become a heroic tragic figure, her dignity and determination in the face of ironic social injustice touching people across the United States and inspiring calls for change. Her story has circulated widely in the national news across media (print, radio, and broadcast television) and in social media as well (there is a tribute to her on YouTube on the first anniversary of her death). It has generated outrage and helped shape a major effort to change national policy, with President Obama and the Secretary of Labor evoking her experience in advocating for change under the banner of 
A public secret

"Taking Care of Those Who Take Care of Us." Evelyn Coke has, in short, become a potent symbol of the failure of our society to support workers who care for our most vulnerable people in old age. "I loved my work, but the money was not good at all," she was quoted as saying in the New York Times in March 2007, a month before the Supreme Court heard oral arguments (Greenhouse 2007). In the same story, the president of Long Island Care is reported to have insisted that providing overtime for homecare aides would cost too much and put her company at risk, adding it would be "horrendous for the entire industry." (What is missing from this story? I would have liked to have learned about the experience of those who had been helped by Evelyn Coke.)

Coke's story has also been taken up by scholars. In Forced to Care: Coercion and Caregiving in America (2010), Evelyn Nakano Glenn returns to the story of Evelyn Coke several times. ${ }^{10}$ Glenn's purpose is to call attention to the crisis of care we are facing in the United States and to trace over the course of American history the systematic underlying and interlocking forms of coercion that subtend what she refers to as "the social organization of caring," the features of which include reliance on the private sphere of the family, the feminization and racialization of care, the low status of care work and care workers themselves, and, since the 1970s and the turn to neo-liberal economic and political policies, the increasing disavowal of the state of responsibility for such care (5). ${ }^{11}$

What image do we find on the cover of Glenn's book? It is in fact Lars Klove's photograph, rendered in tones of brown that subtly racialize the black-and-white image; the word "forced" is in red, draining the simple sentimentality from the scene. In the context of the book cover, we are asked to read the photograph "Mature and Young Hands" as ambiguous and ambivalent, the touching hands symbolic of the intertwined relationship between the person cared for and the caregiver, a complicated relationship that can be affective in a positive sense, but is also complexly mediated by cultural beliefs, public policy, and social institutions (including most prominently, the family and the market). Forced to care: this was

\footnotetext{
${ }^{10}$ For other scholars who refer to Evelyn Coke, see Stacey 2011; Boris 2011.

${ }^{11}$ See Hoff, Feldman, \& Vidovicova 2010 on migrant home care workers and older people.
} 
International Journal of Ageing and Later Life

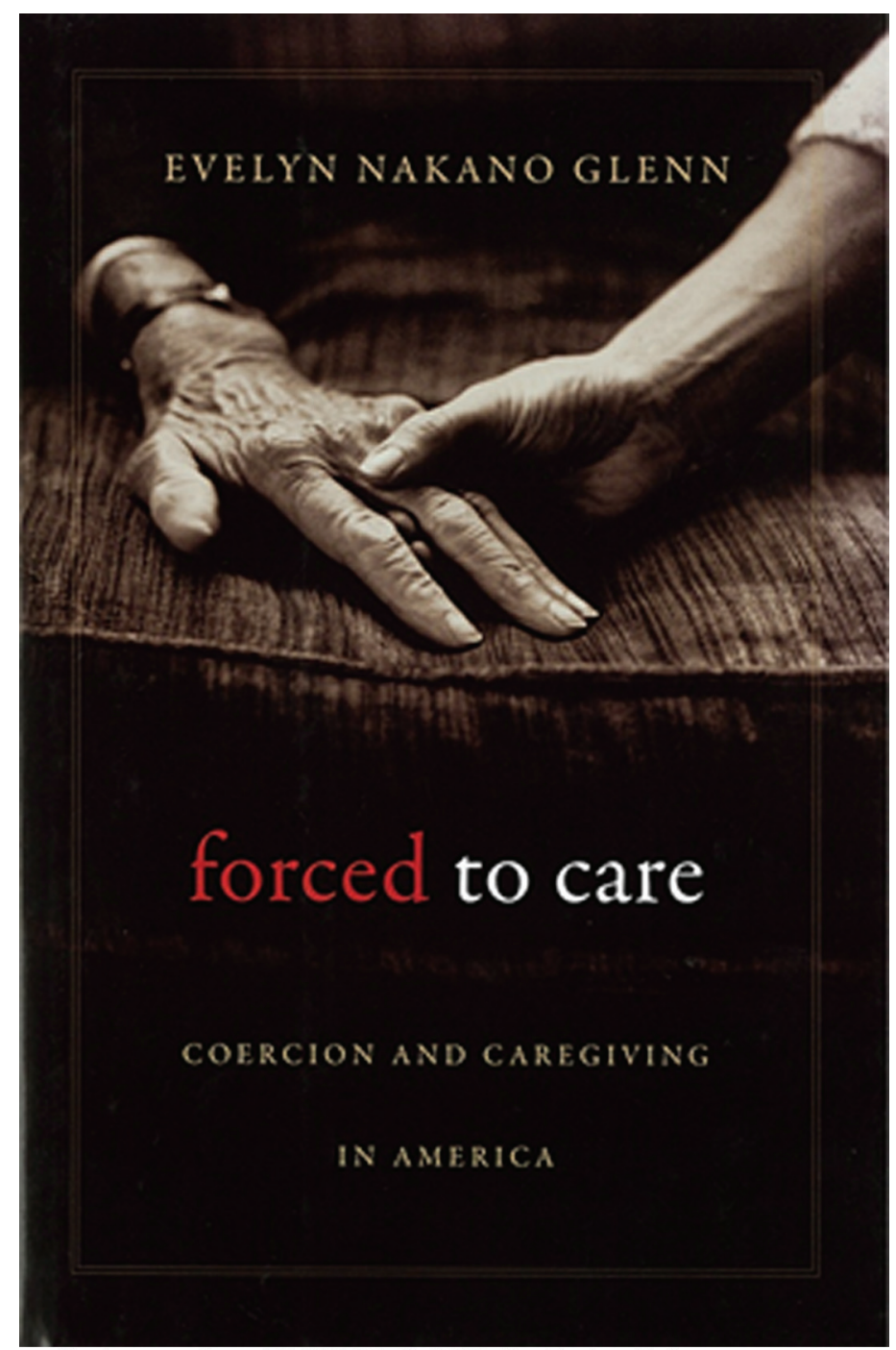

Book cover from FORCED TO CARE by Evelyn Nakano

Glenn appears courtesy of Harvard University Press,

Copyright $(02010$ by the President and Fellows of Harvard College. 
A public secret

the situation of Evelyn Coke, whose experience speaks to that of so many women of color in the United States.

I will not rehearse Glenn's persuasive argument here. But I do want to note that she opens her book by identifying the rapidly growing elderly population in the United States as the key index of our intensifying crisis of care. Similarly, Kittay, in introducing the concept of dependency work, begins her influential book Love's Labor with a reference to care of the elderly, citing a story of a poor 95-year-old black woman, frail and growing blind, who took care of others for most of her life and now has only her own family to count on to care for her. The focus of both Glenn and Kittay on caregivers and the elderly is as rare as it is urgent. For decades feminists have been concerned with issues of reproductive rights and child care, equal opportunity and equal pay for equal work, and sexuality and gender identity. But not with aging. ${ }^{12}$ In the United States the notion of work-life balance, for example, has been associated predominantly with the care of children. But today, as Glenn insists, the "new frontier" of work-life balance is that of care of the old and of disabled relatives (3) ${ }^{13}$ Race is a significant part of the equation. Indeed this public secret has been the case for years, as writer Ted Conover's remarkable piece in the New York Times Magazine in 1997 attests and to which I now turn. As he writes, "Nursing is one of the few careers traditionally open to women in Jamaica-a fact that dovetails nicely with Americans' growing needs" (127).

\footnotetext{
${ }^{12}$ According to the Family Caregiver Alliance, it is estimated that $59-75 \%$ of caregivers in the U.S. are women (qtd in Geist 2009: 163).

${ }^{13}$ The afflictions of aging and of disability often converge, although Glenn does not discuss it. Social scientific research in other countries calls attention to the effect that population aging is having on the growth of care employment in the context of the shrinking public role of the state. See Peng 2010 on careworkers in Korea, and Doyle \& Timonen 2010 on migrant caregivers of the elderly in Ireland; in the latter study it was found that caregivers preferred working with the elderly to working with children.
} 
International Journal of Ageing and Later Life

"In the countryside, we always take care of old people ourselves."

The expository point of Conover's magazine-long feature story "The Last Best Friends Money Can Buy" is the "dilemma" of care for the elderly in the United States (132). Conover cites statistics about aging and the costs of different kinds of care. But at the core of "Last Best Friends" is the story he tells of the two women of color (both are Jamaican immigrants in their thirties) who cared for a 90-year-old New York woman (she is white) during the last months of her life. Testimony to Conover's sensitivity and skill as a writer, "Last Best Friends" conveys the complex worlds of these women, charged with difficulty and with meaning.

A superb example of the genre of a magazine feature story, "Last Best Friends" departs sharply from a formulaic news story that opens with a brief anecdote (so-and-so, age such-and-such) and then moves rapidly to the generalization it serves; I call this news genre an "information-story" (Woodward 2009). Designed to alert us to predicaments and problems, an information-story does not open up a space for thinking and feeling; an information-story precludes the possibility of representing subjectivity at the level of the individual. Striving for generalization, an informationstory tends to instrumentalize norms without regard for particularity. In contrast, with "Last Best Friends," which is much longer than a feature story in a daily newspaper, the story of the people involved is the heart of the piece, not metrics of health care. And the story features the caregivers.

Conover introduces us first to Lorna Kingston who, wearing a pale yellow suit, is interviewing for a position as a home health worker at Rose Enselman's New York Central Park West apartment. Lorna is hired and, after taking daily care of Rose grows harrowing, indeed impossible for one person, she is joined by Claudia Piper. The last paragraph of Conover's piece - it is now several months after Rose's death and the small funeral attended by both of them - returns us to Lorna and Claudia, who have grown as close to each other as they had become attached to Rose. If Lorna does not use the language of family, she does express her attachment to Rose after her death: "You hurt, you feel it, to know that she's gone, because we really got close to her" (150). Like Clendinen writing of Louise Edwards, Rose's nephew acknowledges at the funeral the role that Lorna Kingston and Claudia Piper (and three other people) played in his aunt's 
A public secret

last days: "I think in the last days these were the most important people. And I think Rose would want me to thank them" (152).

If Lorna Kingston and Claudia Piper as caregivers open and close the story, the superb photographs, taken by Scott Thode, that accompany the piece inside the Magazine also tell us that this is first and foremost their story. The first photograph, filling a full page of the magazine and spreading over the fold, is of Lorna and Claudia. Throughout the story, the photographs that focus on the two of them are large and in color, while the three photographs of Rose Enselman are small and in black and white.

One of the underlying contrasts of "Last Best Friends" is that of two systems of value regarding care, one neoliberal (although Conover doesn't

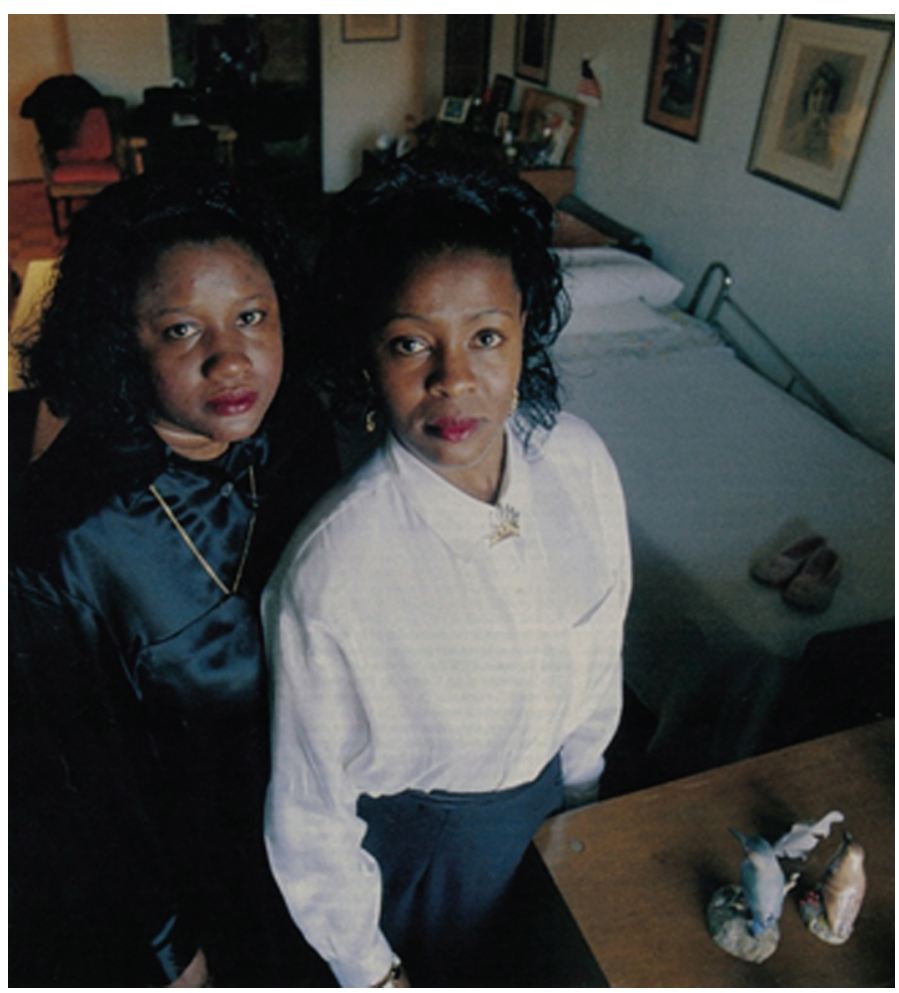


International Journal of Ageing and Later Life

use the word), one I am tempted to term traditional, relying upon members of a family to care for each other, even though Lorna had to leave behind her two children when she came to the United States. But the contrast seems to rise organically out of the story of these women rather than being an idea - or a debate - that structures the article. In the course of "Last Best Friends" we also learn that Lorna is sending money back to her sister in Jamaica. Her mother, her aunt, and her stepmother have all immigrated to New York where they are care workers. They are proud of what they do and are baffled if not appalled by the way American families do not care for their old ones themselves. Yet there is a contradiction here. We also learn that Lorna can't imagine returning to Jamaica when she is old herself. Conover visits Lorna's grandmother in Jamaica and reports these conversations:

A hundred feet down the road from Lorna's childhood home lives her grandmother, Claribel Brown, age eighty-three. She serves visitors a plate of small, sweet bananas and says that when she's too weak to care of herself, there are many, many relatives nearby who will step in. "All my life I took care of children," she says. "Now they carry me."

I report this to Lorna and ask who will take care of her when she's an old lady. Would she never consider Jamaica? She shakes her head. "I talk to Junior about it [her son who lives with her in New York]. He already says he won't put me into a nursing home. He say, 'Mama, I'm going to get you the best care there is. And I'm going to check on it all the time to make sure you get it."'

Then she voices a very American sentiment: "And I sure hope he don't forget." (pp. 147-148)

Who will care for the caregiver?

As the experience of Lorna Kingston suggests, it does not seem remotely possible that the practices of care these women bring with them from Jamaica will transform care for the elderly in the United States, effecting transnational social change from below. I expect instead that as demand for care grows in our increasingly aging society, so too will the global flow of caregivers to the United States, with one generation replacing another. ${ }^{14}$

\footnotetext{
${ }^{14}$ Important work has been done on the effects of migration on caretaking in the country of origin. See anthropologist Parrenas who, studying Filipina domestic workers, names what I see as a domino effect, the "international transfer of caretaking" (2000: 561).
} 
A public secret

How can we best draw attention to this public secret? How can we engender concern so that people will come to care for and care about the frail elderly and their caregivers? Ted Conover's piece suggests one important way to tell these stories: that we focus not on the elderly person in isolation, as does the photograph I referenced at the opening of this essay, and perhaps not even on the older frail woman in the foreground, but rather in relation to those who care in both senses of the word, so that we become witnesses to the experience of everyone involved in the scene of care. Consider, for example, the photograph on the cover of the New York Times Magazine featuring Conover's piece. A beautiful chiaroscuro image of Lorna Kingston and Rose Enselman, its religious overtones convey the strength of compassion in the face of imminent mortality, and the comfort that comes from intimate and enfolding care. It should not go unnoticed that the clasping of hands, both black and white, is central to the image and is unambiguous in its tone of soothing care. That tone is undermined on the cover, however, by the colloquial and infantilizing nature of the article's title - "The Last Nanny" - as well as by the ominous teaser, designed to elicit panic and then quell it, spelling danger of a melodramatic kind: "Living longer often means being left with a stranger. The boom in elder care creates new relationships, fraught with fear, guilt and even love."

Conover's piece itself is not guilty of black-and-white melodrama. I have been stressing his emphasis on the two devoted women who cared for Rose Enselman. What is also exceptional about "Last Best Friends" is the extent to which Conover draws so many other people into the scene of care, giving us their perspectives. All have crucial roles to play, almost all are named. There is Enselman's nephew, her closest relative. Enselman's friend (she is generations younger) who lives in the same apartment building. The housekeeper who comes once a week (she has been coming for years). Rose's geriatrician. Her care manager. The social worker who checks on her every week. The accountant. Together they form an assemblage of many moving parts in a neoliberal global economy, managing Rose's care, yes, but caring in many different affective ways, performing different functions. For Rose Enselman, for Lorna Kingston, and for Claudia Piper, the scene of care, although photographed predominantly in terms of two people in an intimate relationship, is founded on a complex foundation of many relationships. The very number of people involved may lead us to suspect 
International Journal of Ageing and Later Life

that Rose Enselman was wealthy. But this was not at all the case. Conover tells us that she had a yearly income of some $\$ 19,000$.

"I worry about all old people. It's out of love."

Conover's story is an example of a magazine-long feature story by a single author. Israeli Tomer Heymann's film Paper Dolls, first undertaken as a sixpart television series, is an example of collaboration in a visual medium with the primary subject that of a disasporic subculture. ${ }^{15}$ If Conover's story focuses our affective attention in roughly equal measure on both the caregivers and the elder who needs care, Tomer Heymann's documentary film, released in 2006, shifts the dominant measure of attention to the caregivers of the elderly. ${ }^{16}$ If the story of Lorna Kingston and Rose Enselman speaks to the way in which caregiving in the United States by members of the family is rapidly being replaced with a service economy that is part of a globalized market, Paper Dolls depicts the phenomenon of global care chains more dramatically - both in terms of geographical reach and in terms of national policy far more unforgiving than that of the United States, one that renders the lives of migrant caregivers politically perilous.

Paper Dolls challenges our expectations regarding caregiving in terms of gender roles, although it ultimately confirms them in an unexpected way. The film does not focus exclusively on caregiving and the frail elderly, thus capturing the attention of people who might otherwise turn away from

\footnotetext{
${ }^{15}$ See communications scholar Ashuri 2010 on the strategies used by the filmmaker to negotiate with the television industry in order to make the series, which turns on the representation of the foreign and the familiar.

${ }^{16}$ Some viewers may regard the occupation of these migrant workers as incidental or tangential to the main themes of the film. As Heymann himself has said, "For me the movie is ... about being an outsider, especially in this story there are many levels of being [an] outsider. These people came from the Philippines to Tel-Aviv so [that] first of all they are outsiders here in Israel. Second because the government changed the [law], they became illegal workers here. They can be checked by the immigration police. Even in the Philippine community they are quite outsiders because they are not 'classic gays', they are transsexuals and they work with old Jewish orthodox - which [means they are outsiders] in other outsiders, because even these Jewish people are kind of outsiders here in Israel." Qtd. in Ashuri 116.
} 
A public secret

the subject of elder care. It attracts our interest in spectacular terms and with stakes that are dangerously high, framing the portrayal of the mundane daily demands required of the caregivers not only by their weekly late-night performances in fabulous drag as the cabaret dance group Paper Dolls, but also in terms of escalating political animus directed at migrants. In Busby Berkeley musical-film fashion, the opening credits feature choreographed cartoon-like images of lipsticks and combs, high-heeled shoes and microphones, hairdryers and scissors, with the high-spirited dimension of the film captured in the publicity still below. Ominously, the opening credits also feature fighter planes and handcuffs. The work of caregiving is only part of the complex story, told with the informal close-up aesthetic of home movies and first person plural documentaries. As spectators of the film, we witness a full spectrum of emotion on the part of these caregivers ranging

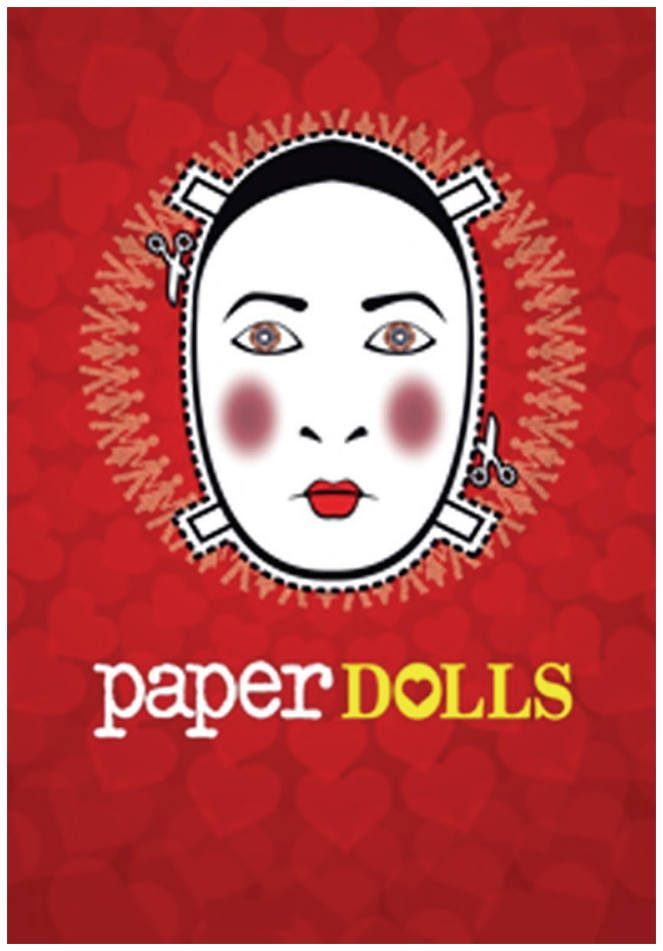


International Journal of Ageing and Later Life

from resignation and grief to high spirits and joy. Central are the emotions of love and longing nourished by the Christian religion and strong family traditions, as well as the political feelings of anger and depression provoked by the repressive measures of the state.

Paper Dolls follows a small group of Filipino transsexuals, men identifying as women ranging in age from 27 to 40 who have left the Philippines to escape severe constraints surrounding sexual identity and practices, coming to Israel to work as caregivers of elderly Jews in an ultra-orthodox suburb of Tel Aviv. Consider the engaging 36-year-old Sally (named Salvador at birth), who has been in Israel for seven years. Open and expressive, she has been caring for three years for Haim Amir, the 80something-year-old man she calls Papa. Speaking of her sexual identity, she tells the filmmaker she feels "free" in Israel. Speaking of her life in general, she says she is "happy." What is hardest is missing her mother, especially not being able to take care of her, which is also central to her identity. "I worry about all old people," she says, "It's out of love ... If I were in the Philippines I would do this for my mother."17 Sally identifies as Haim's "only daughter," which is all the more striking because in fact he has a daughter, as well as a son. Having returned to the Philippines to visit her mother (Sally hasn't seen her for six years), Sally longs to come back to Israel, drawn by Haim and by her community of the Paper Dollsand she does. Notwithstanding their extreme differences, over time, and in the space of daily care both intimate and mundane, she and Haim form affectionate bonds of kinship modeled on the nuclear family.

In what for me is one of the most remarkable moments in the documentary - it comes toward the end - Haim is asked by the filmmaker for his response to Sally's identity as simultaneously being both a man and a woman. Portrayed as a sweet man intent on teaching Sally to read Hebrew aloud properly, he answers, "I got used to it. That's life." While this may sound flat when read in this essay, in the documentary his answer combines a matter-of-factness with a knowledge of acceptance won over a long period of time, an attitude we might be tempted - appropriately soto call wise. How does he express his acceptance, which is a sign of

17 This is what Leeson \& Hoff 2006 call, in analogy to the "brain drain," a "care drain." 


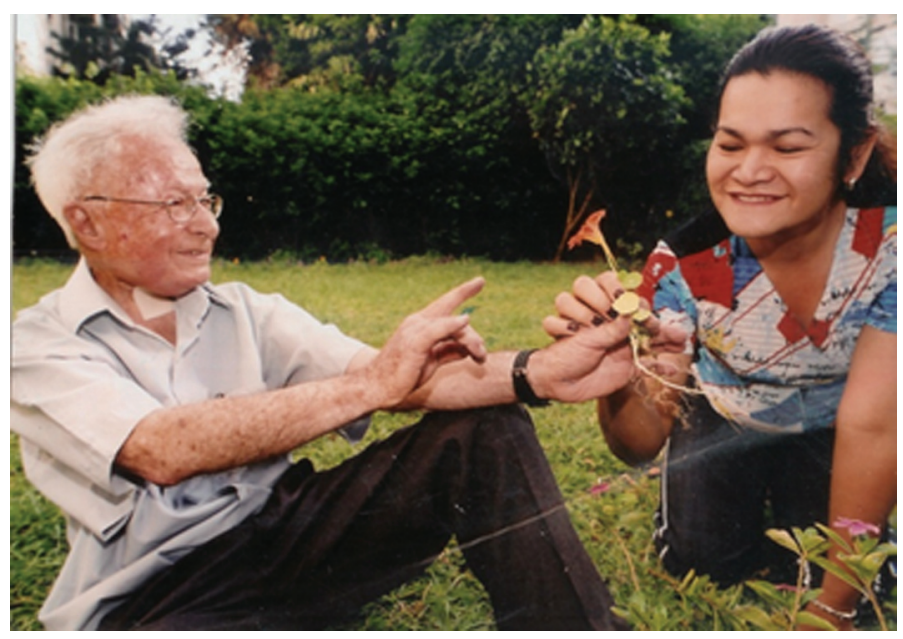

affection? There are many ways, but one of them in particular makes me smile: he offers her a matching skirt and blouse as a gift. Within the world of the documentary, we could say that a moral relationship between Sally and Haim has been created by engendering understanding and creating ties of reciprocity, including emotional reciprocity.

Sally and Haim are both extremely vulnerable when considered in isolation as individuals; together they form a resilient couple attached by strong emotional bonds - by concern, care, and connection, by a feeling of security. They are together to catch each other if and when they fall. As the film follows Sally to Haim's funeral, we see how in the ritual of grieving for him she claims kinship publically, expressing her indebtedness and the meaning their relationship had to her. Should we discount their attachment to each other as merely a superficially sentimental portrayal on the part of the filmmaker of a single relationship? Should we be skeptical of Sally's articulation of what is presented as traditional Filipino values? Is the rhetoric of love empty?

The documentary suggests otherwise - and not only for Sally. Cheska (born Francisco), 38, depicted predominantly as depressed in the film (she has lost her job), says, "We have love, we are very devoted ... We respect old people." Consider also the 27-year-old Jan (born Troan Jacob). Less openly expressive than Sally, tentative, somber, perhaps pensive, Jan is 
International Journal of Ageing and Later Life

fired from her job after six years (a younger Filipino is hired in her place). As she tells the filmmaker, she was as attached to the family she cared for as if they were her mother and father. ${ }^{18}$ At the end of the film we see Jan, easy and friendly and smiling, taking care of an old woman at a Jewish Care Center in London. We see Giorgio (born Eduardo) there as well, reassuring an old woman in a soothing voice. ${ }^{19}$ We are meant to understand that the Paper Dolls do not regard this dimension of their work as exploitative but rather as meaningful. While we may be skeptical of the discourse of family as concealing the oppressive nature of paid carework, we need also to attend seriously to what caregivers say in such situations and not dismiss their descriptions out of hand. For Louise Edwards, the faithful caregiver of Dudley Clendinen's mother, "family" described the relationship between his mother and herself perfectly. ${ }^{20}$

Are these men who are women forced to care? This is a difficult question, and the answer must be yes as well as no. It is clear that few jobs are available to them in a global economy. It is also clear that for any particular culture we would want to undertake a historically specific analysis of

18 See Manalansan 2010 on "the emotional undercurrents of Filipino flexible labor" (215). While I find fascinating his point that the figure of Jan provides an instance of disaffection, "a counter-example of negative feelings that showcases the ambiguity of affective regimes of care and labor" (221) and of "managed alienation and a tempered hostility to the regimes of power and nurturance" (222), I do not think the film taken as a whole supports this reading.

${ }^{19}$ At the risk of being misunderstood as essentializing the capacity for caregiving on the part of Filipinos, I refer to ethnographer Degiuli 2007 who has studied migrant domestic careworkers of the elderly in Italy. She quotes a 40 -year-old Filipina woman who reported she did this difficult work for three reasons: "because I hate the cold and I don't want to be running all over town from one job to another, because I was a nurse obstetrician in the Philippines and I know what it means to take care of people. For us in the Philippines the elders are like precious artifacts in a museum. We need to take good care of them. I was used to taking care of my grandmother and I grew up valuing elders. And, finally, because I like it, I call it a vocation. I can do this job even with my eyes closed" (204).

${ }^{20}$ In her now classic work on emotional labor in a service economy, the sociologist Arlie Hochschild argues that performing such work results in people being alienated from themselves; these stories tell a different story. See Stacey 2009 on the reward of caring (85-136). 
the role of caregiving and domestic work, as does Glenn in Forced to Care: Coercion and Caregiving in America. ${ }^{21}$ These five Papers Dolls-Giorgio, Jan, Sally, Chiqui, and Cheska - are part and parcel of a distinct subculture and take obvious pride in their work. I would speculate that the very fact caregiving is associated with women is appealing to them. They also plainly declare that honoring old people through giving care is a basic value of Filipino culture; we should have no reason to second-guess them. This is a value I wish we all shared around the globe. Instead, global labor markets move love as surplus value, as a commodity, and as an export from one country to another-in the process commercializing intimacy. As we have seen in Paper Dolls, in the best of cases what is created is a feeling of kinship as new forms of family take shape, even as the ideology of the individual bearing the burden of risk intensifies around the globe. Indeed it is all the more important for that because, it must be stressed, both the caregivers and the elders are vulnerable. As Nancy Folbre (2001) has memorably said, "the invisible hand of markets depends upon the invisible heart of care" (vii). Paper Dolls renders visible this public secret.

Why has the scene shifted to London? If in the United States there is no requirement at a national level that home care workers be paid either minimum wage or overtime, in Israel "the situation" for these caregivers is far, far worse. At the beginning of the film, simulated headlines of a newspaper sketch the historical context for us:

In 2001, With the Rise of the Second Intifada,

Israel Closed Its Doors to Palestinian Workers.

To Replace Them,

the Israeli Government Opened the Doors to More than 300,000 Workers.

\footnotetext{
${ }^{21}$ See Ray \& Qayum 2009 whose study (Kolkata is their focus) of what they call a "culture of servitude" concludes that the "site in which domestic labor is performed and the labor relation itself entail a culture of servitude, in both the North and South, in which domination/subordination, dependency, and inequality are articulated and rearticulated" (187). My point is that their model does not account for a relationship such as that between Sally and Haim, one not based on such clear-cut divisions of domination/subordination, dependency, and inequality.
} 
International Journal of Ageing and Later Life

After 2001, the situation of migrant workers became particularly precarious, because if they were fired, their visas were instantly revoked, rendering them illegal in the country. In the course of the film the mood grows dark. Bombs and sirens puncture the night and reports of foreign workers being deported are broadcast on the news. In the course of time the unemployed Cheska is caught by the police, jailed, and sent back to the Philippines. At the end of the film, Jan, Giorgio, and Chiqui all leave Israel for England where there is at least a possible path to citizenship for them (Chiqui becomes a head nurse, and Jan, after an entire year, finds work as a caregiver to an elderly Jewish man). Sally, after the death of Haim, returns to the Philippines.

The film thus documents the restless global flows of caregivers, or global care chains. But the metaphor of the chain, which implies strength and fixity, is inapt. If these are commodity chains, from the point of view of the workers there is nothing strong about them. They break easily. These care workers are right to blame the agencies that consider them disposable. But more generally it is the state of Israel that is responsible, relying as it does upon migrant workers to care for its citizens even as its citizens are contemptuous of these Filipinos. As transsexuals in particular and as Filipinos in general, they are despised by many and considered curiosities by others. The filmmaker quotes an Israeli taxi driver (he has just dropped two of them off at a nightspot) who rails, "Two disgusting creatures, I don't know what to call them. They disgust me as men and as fake sleazy women ... That place" (he is referring to the Philippines) "is the devil's cradle, the origin of all evil. Here they pretend to 'take care of old people'." The climate is poisonous - racist and violent. Jan, Giorgio, and Chiqui must start over in another city in another country. But if the three of them begin over as caregivers, they also resume performing as Paper Dolls, albeit in reduced number. As the film moves toward the closing credits, we see all three on a London stage. They are exotic showgirlsthey are the Paper Dolls from Israel after all!- -dancing with elan, their long earrings dangling, their paper dresses swaying. We are reminded that if this is a documentary, one that was in the making for five years and bears the signature of reality, it is one that has been artfully shaped. 
A public secret

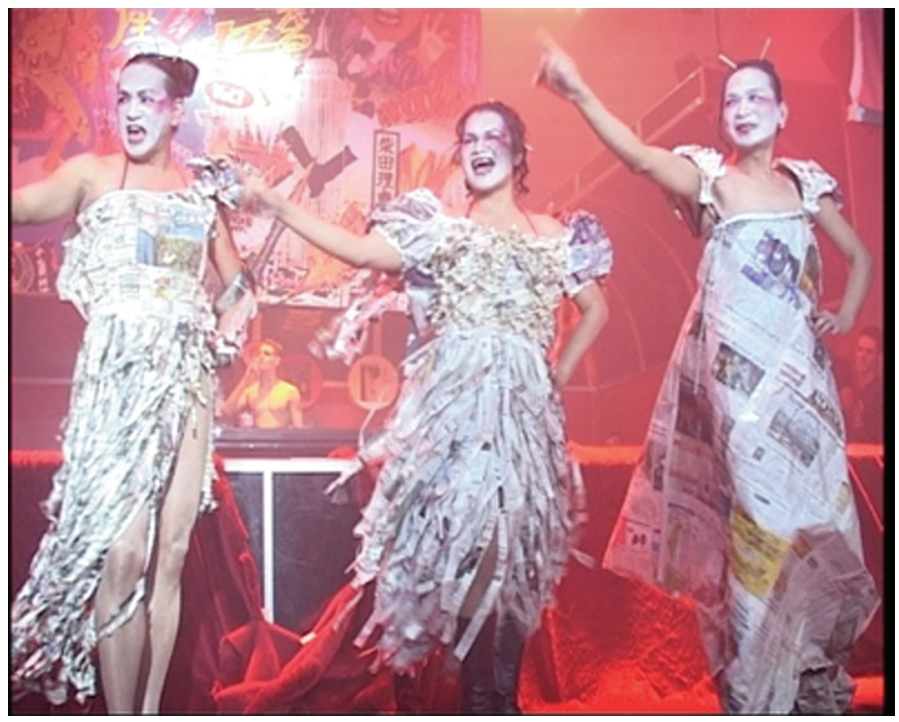

Who will take care of these caregivers? We do not know. The film cannot follow them into the far future. But the prognosis cannot be good, both at this moment in their lives and in a distant old age to come. If urbanization, globalization, and population aging are the three decisive trends of our time, there would seem to be a perfect storm in the making. Jobs - new good jobs - need to be created worldwide if we are not to experience waves of conflict and violence and long periods of economic recession, if not depression in the future. Given that many of our nation-states are divesting themselves of responsibility for vulnerable populations, brutally slashing social programs, how do we and how will we care for the frail elderly? Care for the caregivers? As age studies theorist Rudiger Kunow (2010) insists, "age" is "a critical horizon against which processes of 'globalization' have to be analyzed and questioned" (295).

\section{III}

The intersection of globalization and population aging of nation-states entails flows of migrant workers to care for the elderly, flows I have no 
International Journal of Ageing and Later Life

doubt will increase as populations continue to age, with workers at serious risk as Paper Dolls illustrates. At a conference entitled "Does Europe Care," held in Amsterdam in April 2011, the phenomenon of migrant workers, who are undertaking elder home care across Europe, was a special focus. As the conference Web site acknowledges, "The self-evident assumption that there will (always) be a government system that will take responsibility for the care of one's next-of-kin is crumbling." (Such a system has never been in place in the United States.) The photograph with which I opened this essay - an old woman alone on an unwelcoming benchspeaks to this state of affairs. Just as there is no such thing as a baby, as Winnicott famously said, there should be no such thing as a solitary old person. Belonging is a requirement of our blood and bones. The problematic "solution" in the making is migrant careworkers-in Europe, in the United States, in Israel, and in other places around the globe. As anthropologist Francesca Degiuli (2007) has reported in an ethnographic study on elder caregivers in an Italian town, "In recent years, it has become more and more common to encounter in parks, crowded street markets and grocery stores, odd looking couples who were, until a few years ago, unfamiliar to Italian eyes. They most often comprise migrant women, often of color, and frail Italian elders, sometimes self-sufficient, sometimes confined to wheelchairs" (193).

Supplanting traditional forms of care, these market-regulated forms of "service" are woefully inadequate in many places in building mutual respect and solidarity (Baars 2006: 33). Cases may prove the exception to this generalization, as we have seen in Paper Dolls, "Last Best Friends," and Clendinen's A Place Called Canterbury. In these three instances, strong ties were forged notwithstanding the callousness of the state and the low pay of the caregivers. But as we know, and the experience of the late Evelyn Coke exemplifies, the situation of caregivers of the frail elderly is both precarious and grossly unjust. One of the key points of "Does Europe Care" is that "informal carers" (understood, as opposed to the United States, to mean workers who provide care in a private home) should be recognized as entitled to better training, to protection by government regulation, and to support for greater inclusion in the society in which they work. We need this as well in the United States. Yes, we should advocate for better working conditions. But in a perverse contradiction that is 
characteristic of globalization, better working conditions will in turn render the system of global care chains - a system that through the domino effect perpetuates the precariousness of care at local levels in the nations which export caregivers-stronger.

At stake is the fundamental human need to belong to meaningful social spheres - to experience the feeling of security that is, hopefully, the feeling of family - and, in contemporary democratic societies, to exercise the rights of citizenship. I agree with Glenn that care should be a key feature of the rights and entitlements of citizens and that this would necessarily entail recognizing the important work done by caregivers as an essential contribution to the public good; this she calls social citizenship (190-91).

How can we heighten concern and move people, governments, and other institutions to care? As I have been suggesting, one way to press for changes in social policy is by telling stories of caregivers and elders together. Morally and theoretically, this is the right thing to do. It might also be more palatable and persuasive to more people. Telling stories: this is a practice that exemplifies the narrative turn in gerontological studies, one that pushes beyond the framework of gerontology itself to embrace the question of caregiving across generations and in the context of globalization. In what form might these stories take hold and make a difference?

The pragmatist philosopher Richard Rorty, in an essay published almost 20 years ago, referred to the decisive influence of Harriet Beecher Stowe's novel Uncle Tom's Cabin on the abolitionist effort in the United States in the 19th century. ${ }^{22}$ I am skeptical that a mass-market novel would have such an effect today. I remember vividly a leader of the embryonic Palestine Liberation Organization in New York telling me in the early 1960s how incalculable was the damage done to their cause by Otto Preminger's 1960 influential film Exodus. I doubt a fiction film could have the same

\footnotetext{
${ }^{22}$ Rorty has argued that we have made significant progress since the Enlightenment in terms of the sentiments, having increased our capacities "to see the similarities between ourselves and people very unlike us as outweighing the differences" (15).
} 
International Journal of Ageing and Later Life

force today. Today I suspect that stories with a documentary and auto/ biographical impulse that are drawn from everyday life, as are the four I have considered, will serve us better; it is as though these modes, rather than fiction, draw us closer to what is real, bringing what is generally understood as private into the public domain. Moreover, stories that embrace a broad spectrum of feeling, stretching beyond sympathy, have more power to engage us. The story of Evelyn Coke inspires both admiration and sympathy. The stories told by Ted Conover and Tomer Heymann lift caregivers and elders out the one-dimensional frame of victimhood. Isolated and separate, caregivers and elders are vulnerable. Together, caregivers and elders are strong.

We need to create a capacious archive of feelings, a storehouse of stories that will have a cascading effect on individuals, families, communities, and policymakers. ${ }^{23}$ I have grown attached to these stories - to the people in these stories. But an archive implies something out of the public eye. How can we as scholars insert ourselves into the circuitry of debate and help influence the values that guide policy? How can we make our research and scholarship live in larger publics? The American anthropologist Luisa Margolies (2010), after writing a book about taking care of her mother, found that in order to circulate her story she needed to seek out her local radio stations to carry her message to other publics, translating her experience so that others could hear her. As scholars and researchers in age studies, we need to move beyond the closed professional circles of academic knowledge. ${ }^{24}$ We need to make clear the intersection between the fresh work being done in our fields and the public interest and the public good. We have doctors without borders. We need scholars without borders in age studies, scholars who understand that it is important not just to think globally and act locally but also to think locally and act globally - and who will call attention to the public secret of the caregivers of frail elders.

\footnotetext{
${ }^{23}$ See Cvetovitch's An Archive of Feelings for an important discussion of the subgenre of lesbian AIDS memoirs which focus on caregiving and "resist any firm distinction between caretaking and activism" (2003: 212).

${ }^{24}$ See Basting 2009; Gullette 2011.
} 
A public secret

\section{Acknowledgements}

A version of this essay was originally presented at the conference on "Theorizing Age: Challenging the Disciplines" at the University of Maastricht in October 2011. I am grateful to Aagje Swinnen for her welcome invitation to this intellectually exhilarating conference as well as to Elena Fronk and many of my colleagues in age studies - Roberta Maierhofer in particular, without whom this essay would not have been possible, and Cynthia Port, for her guidance. I thank Ros Jennings, who organized the forward-looking conference on "Women, Ageing, and the Media" at the University of Gloucestershire in December 2008, Martin Manalansan IV who introduced me to the remarkable documentary Paper Dolls, Amy Bhatt who referred me to Cultures of Servitude, Engin Isin, the principal investigator of the Open University's project Oecumene: Citizenship after Orientalism, who gave me permission to reproduce "Sitting on a Bench," his photograph of the old woman, the photographer Scott Thode, who gave me permission to reproduce his photographs accompanying "The Last Best Friends Money Can Buy" in the New York Times Magazine, and video documentarist Tomer Heymann, who gave me permission to reproduce promotional material and stills from Paper Dolls.

\section{Corresponding Author}

Kathleen Woodward, Simpson Center for the Humanities and Department of English, University of Washington, Seattle, USA. Email: Kw1@uw.edu

\section{References}

Ackerman, D. (2011). One Hundred Names for Love: A Stroke, a Marriage, and the Language of Healing. New York: W. W. Norton.

Ashuri, T. (2010). Negotiating distances: The cultural economy of television programs. Television and New Media 11(2): 105-122.

Baars, J. (2006). Beyond neomodernism, antimodernism, and postmodernism: Basic categories for contemporary critical gerontology. In J. Baars, D. Dannefer, C. Phillipson \& A. Walker (eds.), Aging, Globalization, and Inequality: The New Critical Gerontology (pp. 17-42). Amityville, NY: Baywood. 
International Journal of Ageing and Later Life

Barnes, N. (2010). Life which is ours to know just once. In N. BauerMaglin \& D. Perry (eds.), Final Acts: Death, Dying, and the Choices We Make (pp. 33-54). New Brunswick, NJ: Rutgers University Press.

Basting, A. (2009). Forget Memory: Creating Better Lives for People with Dementia. Baltimore, MD: Johns Hopkins University Press.

Boris, E. (2011). Race, gender, and pay discrimination. In T. Thomas \& T. Boisseau (eds.), Feminist Legal History: Essays on Women and the Law (pp. 240-256). New York: New York University Press.

Clendinen, D. (2008). A Place Called Canterbury: Tales of the New Old Age in America. New York: Viking Press.

Cohen, E. (2011). The paradoxical politics of viral containment; or, how scale undoes us one and all. Social Text 29: 15-35.

Conover, T. (1997). The last best friends money can buy. New York Times Magazine, 30 November.

Cvetovitch, A. (2003). An Archive of Feelings: Trauma, Sexuality, and Lesbian Public Cultures. Durham, NC: Duke University Press.

Daniel, S. (2007). Public secrets. Vectors 2(2). Available on http:// www.vectorsjournal.org/projects/index.php?project $=57$ (Accessed: November 17, 2011).

Degiuli, F. (2007). A job with no boundaries: Home eldercare work in Italy. European. Journal of Women's Studies 14: 193-207.

Does Europe Care: European Conference on Long Term Care and Diversity, Amsterdam (2011). Available on http://www.careconference. eu/site (Accessed: November 17, 2011).

Doyle, M. \& Timonen, V. (2010). Obligations, ambitions, calculations: Migrant care workers' negotiation of work, career, and family responsibility. Social Politics 17(1): 29-52.

England, K. (2010). Home, work and the shifting geographies of care. Ethics. Place and Environment 13(2): 131-150.

Folbre, N. (2001). The Invisible Heart: Economic and Family Values. New York: New York Press.

Fuchs, E. (2005). Making an Exit: A Mother-Daughter Drama with Machine Tools, Alzheimer's, and Laughter. New York: Henry Holt.

Geist, M. E. (2009). Measure of the Heart: Caring for a Parent with Alzheimer's. New York: Springboard Press. 
A public secret

Gillies, A. (2009). One House, Three Generations, and a Journey into Alzheimer's. New York: Broadway Books.

Glenn, E. N. (2010). Forced to Care: Coercion and Caregiving in America. Cambridge, MA: Harvard University Press. Available on http://www. hup.harvard.edu/images/jackets/9780674064157-lg.jpg (Accessed: December 24, 2011).

Goyder, J. (2001). We'll Be Married in Freemantle. Freemantle: Fremantle Arts Centre Press.

Greenhouse, S. (2007). Justices to hear case on wages of home aides. New York Times, 25 March.

Gullette, M. M. (2011). Agewise: Fighting the New Ageism in America. Chicago, IL: University of Chicago Press.

Heymann, T. (2010). Qtd. in Tamar Ashuri. Negotiating distances: The cultural economy of television programs. Television and New Media 11: 105-122.

Hochschild, A. R. (2000). Global care chains and emotional surplus value. In W. Hutton \& A. Giddens (eds.), Global Capitalism (pp. 13-46). New York: The New Press.

Hoff, A., Feldman, S. \& Vidovicova, L. (2010). Migrant home care workers caring for older people: Fictive kin, substitute, and complementary family caregivers in an ethnically diverse environment (Guest Editorial). International Journal of Ageing and Later Life 5(2): 7-16.

Kane, R. L. \& West, J. C. (2005). It Shouldn't Be This Way: The Failure of LongTerm Care.' Nashville: Vanderbilt University Press.

Kittay, E. F. (1999). Love's Labor: Essays on Women, Equality, and Dependency. New York: Routledge.

Klove, L. (n.d.). Mature and Young Hands. Getty Images. Available on http:// www.gettyimages.com/detail/10169892/The-Image-Bank (Accessed: November 19, 2011).

Kunow, R. (2010). Old age and globalization. In T. R. Cole, R. E. Ray \& R. Kastenbaum (eds.), Guide to Humanistic Studies in Aging: What Does It Mean to Grow Old (pp. 293-318). Baltimore: Johns Hopkins University Press.

Lawson, V. (2007). Geographies of care and responsibility. Annals of the Association of American Geographers 97: 1-11. 
International Journal of Ageing and Later Life

Leeson, G. W. \& Hoff, A. (2006). Foreign Workers in the Health and Social Care Sector in the United Kingdom. Tokyo: Japanese Council of Social Welfare.

Leland, J. (2008). Coming Full Circle. New York Times, 30 October. Available on http://www.nytimes.com/2008/11/02/education/edlife/ montessori.html? scp=1\&sq=Coming $\% 20$ Full $\% 20$ Circle $\% 20 \mathrm{John} \% 20$ Leland\&st $=$ cse (Accessed: December 24, 2011).

Maierhofer, R. (2010). Generations connecting: Alzheimer's disease and changes of cultural values. Gender Forum: An Internet Journal for Gender Studies 28. Available on http://www.genderforum.org/issues/ engageing-questions/generations-connecting-alzheimers-disease-andchanges-of-cultural-values/ (Accessed: November 19, 2011).

Manalansan, M. F., IV. (2010). Servicing the world: Flexible Filipinos and the unsecured life. In J. Staiger, A. Cvetkovich \& A. Reynolds (eds.), Political Emotions: New Agendas in Communication (pp. 215-228). New York: Routledge.

Margolies, L. (2004). My Mother's Hip: Lessons from the World of Eldercare. Philadelphia: Temple University Press.

Margolies, L. (2010). The anthropologist as caregiving daughter: Lessons from the world of the frail elderly. Journal of Aging, Humanities and the Arts 4: 119-132.

Martin, D. (2009). Evelyn Coke, home care aide who fought pay rule, is dead at 74. New York Times, 9 August.

Miller, N. K. (1996). Bequest and Betrayal: Memoirs of a Parent's Death. New York: Oxford University Press.

Mol, A., Moser, I. \& Pols, J. (eds.). (2010). Care in Practice: On Tinkering in Clinics, Homes and Farms. Bielefeld: Transcript Verlag.

Oecumene: Citizenship after Orientalism. Available on http://www. oecumene.eu/ (Accessed: November 19, 2011).

Paper Dolls. (dir.) Tomer Heymann (Strand Releasing, 2006).

Parrenas, R. S. (2000). Migrant Filipina domestic workers and the international division of reproductive labor. Gender and Society 14(4): 560-580.

Peng, I. (2010). The expansion of social care and reform: Implications for care workers in the Republic of Korea. International Labour Review 149(4): 461-476. 
A public secret

Rauch, J. (2010). Letting go of my father. The Atlantic, April. Available on http://www.theatlantic.com/ magazine/archive/2010/04/letting-goof-my-father/8001/ (Accessed: November 19, 2011).

Ray, R. \& Qayum, S. (2009). Cultures of Servitude: Modernity, Domesticity, and Class in India. Stanford: Stanford University Press.

Rorty, R. (1993). Human rights, rationality, and sentimentality. The Yale Review 81(4): 1-20.

Roth, P. (1991). Patrimony: A True Story. New York: Simon \& Schuster.

Sheehy, G. (2010). Passages in Caregiving: Turning Chaos into Confidence. New York: William Morrow.

Shulman, A. K. (2008). To Love What Is: A Marriage Transformed. New York: Farrar, Straus \& Giroux.

Simmons, J. D. (1996). Connections: I am my mother's keeper. MS. JulyAugust.

Stacey, C. L. (2011). The Caring Self: The Work Experiences of Home Care Aides. Ithaca: Cornell University Press.

Taking Care of Those Who Take Care of Us. U.S. Department of Labor fact sheet. Available on http://www.dol.gov/whd/flsa/companionship_ factsheet_ENGLISH.pdf (Accessed: August 15, 2012).

Wald, P. (2008). Contagious: Cultures, Carriers, and the Outbreak Narrative. Durham, NC: Duke UP.

Whitney, S. Y. (2011). Dependency relations: Corporeal vulnerability and norms of personhood in Hobbes and Kittay. Hypatia 26(3): $554-574$.

Woodward, K. (2009). Statistical Panic: Cultural Politics and Poetics of the Emotions. Durham: Duke University Press.

Woodward, K. (2012). Assisted living: Aging, old age, memory, aesthetics. Occasion: Interdisciplinary Studies in the Humanities 4. Available on http://arcade.stanford.edu/journals/occasion/articles/assisted-livingaging-old-age-memory-aesthetics-by-kathleen-woodward (Accessed: August 12, 2012). 